\title{
Latin American Startups
}

\section{Startups Latinoamericanas}

DOI: $10.46932 / s f j d v 2 n 2-067$

Received in: March 1st, 2021

Accepted in: May 30th, 2021

\section{Carlos Rios-Campos}

Docente de la Universidad Nacional Toribio Rodríguez de Mendoza de Amazonas. Doctor en Gestión Universitaria. Maestro en Administración. Investigador RENACYT. Bagua, Perú.

E-mail: carlos.rios@untrm.edu.pe

\section{Pilar del Rosario Rios Campos}

Docente Principal. Maestra en Ciencias con Mención en Informática y Sistemas. Ingeniera de Sistemas. Universidad Nacional Pedro Ruiz Gallo. Lambayeque, Perú.

E-mail: prios@unprg.edu.pe

\section{Elixer Alexandra Palma Batalla}

Docente. Grado acádemico.Cuarto nivel Máster Física, Química. Unidad Educativa "Los Guayacanes", Quevedo Los Ríos.Ecuador.

E-mail: correo.elixer1972@hotmail.com

\section{Fanny Esther Renteria Figueroa}

Magister en Ciencias de la Educación. Unidad Educativa Nicolás Infante Díaz. Quevedo. Ecuador.

E-mail: ferefi1966@hotmail.com

Juan Francisco Castro Castro

Ingeniero Eléctrico. Unidad Educativa" Los Guayacanes". Provincia Los Ríos. Cantón Quevedo. Ecuador.

E-mail: frajucascas@gmail.com

\section{Antero Alexander Cabrera Torres}

Docente asociado. Licenciado en Estadística, Maestría en Educación y Doctorado en Administración de la Educación. Universidad Nacional de Frontera. Sullana, Perú.

E-mail: acabrera@unfs.edu.pe

\section{Freddy Manuel Camacho Delgado}

Docente Principal. Doctor en Economía. Universidad Nacional Intercultural Fabiola Salazar Leguía de Bagua. Bagua Grande, Perú.

E-mail: fcamacho@unibagua.edu.pe

\section{Sonia Carmina Venegas Paz}

Docente de la Universidad de Guayaquil. Magister en Ciencias Internacionales y Diplomacia. V nivel del Doctorado en Educación. Guayaquil, Ecuador.

E-mail: punto_maximo_77@hotmail.com 


\title{
RESUMEN
}

Es necesario conocer el estado de las startups. El objetivo general fue determinar la situación de las Startups latinoamericanas. Metodología, en esta investigación se han seleccionado 25 documentos, realizados en el período 2016 - 2021; incluyendo: artículos científicos, artículos de revisión e información de sitios web de organizaciones reconocidas. Las palabras clave utilizadas en las búsquedas fueron: latinoamericanas y startups. Resultados, el Banco Nubank de Brasil y Rappi de Colombia son las empresas unicornios, que están creciendo en América Latina de manera sostenida y logrando posicionarse, recibiendo más financiamiento internacional. Además, se observan startups de otros países de la región, las cuales muestran un crecimiento significativo y son reconocidas en nuevos mercados. En conclusión, la situación de las Startups latinoamericanas es: las startups Fintech están revolucionando la industria financiera en toda América Latina, las startups latinoamericanas tuvieron acuerdos récord de capital riesgo en 2020 y el Banco Nubank de Brasil y Rappi de Colombia son las empresas unicornios.

Palabras clave: Latinoamericano, startups, financiación.

\begin{abstract}
It is necessary to know the state of the startups. The general objective was determinate the situation of the Latin American Startups. Methodology, in this research, 25 documents have been selected, carried out in the period 2016 - 2021; including: scientific articles, review articles and information from websites of recognized organizations. The keywords used in the searches were: Latin American and startups. Results, the Nubank Bank of Brazil and Rappi of Colombia are the unicorns companies, which are growing in Latin America in a sustained way and achieving a position, receiving more international financing. In addition, startups from other countries in the region are observed, which show significant growth and are recognized in new markets. Conclusions, the situation of the Latin American Startups are: Fintech startups are revolutionizing the financial industry across Latin America, Latin American Startups Had Record Venture Capital Deals in 2020 and the Nubank Bank of Brazil and Rappi of Colombia are the unicorns companies.
\end{abstract}

Keywords: Latin American, startups, financing.

\section{INTRODUCTION}

Latin America faces problems with the lack or flight of science professionals, infrastructure, institutional frameworks, and funding of the science and technology sector. Private-public partnerships and foreign investment sometimes create bottlenecks in innovation because of the withholding of information by one party (Soh, 2019).

There are 20 countries that officially belong to the "Latin American region". Almost 640 million people live in these 20 countries over 7.5 million squared miles - 13\% of the world's surface area. Although Spanish and Portuguese are the predominant languages, there are over 800 different languages that are spoken across the region (González, 2017).

Latin America's startup scene has grown in recent years, attracting foreign funds that once considered it a tech backwater with few companies with enough potential worthy of investments Fieser (2021). 
In Latin America, the issue is not whether or not entrepreneurs are up to the challenge, as they have proven their resilience time and time again, but whether investors are willing to make the most of the moment (Mitchell, 2021).

The findings show that women entrepreneurs, but also men, seeking start-up financing and alternatives are a viable source of employment and economic sustainability to mitigate the effects of increasing levels of unemployment worldwide (Kuschel, Lepeley, Espinosa and Gutiérrez, 2017),

Latin America has increasingly been receiving attention from both startups and tech giants. Earlier this month Facebook announced it had named the city of Bogota as home to its most recent startup hub (Castro, 2019).

There is little specific Latin American knowledge that has been incorporated to help reducing this failure rate, most of the entrepreneurial models have been developed for economies with advanced entrepreneurial ecosystems such has Silicon Valley, with economies and cultures that differ from developing economies, there is a lack of data and research on this topic (Liberona, Kumaresan, Valenzuela, Rojas \& Ferro, 2019).

Companies that have bene" ted from VC range from household names like Google, Apple, Facebook and Amazon to Latin American success stories such as MercadoLibre, Netshoes, Globant and Open English (Taylor, 2017).

These proposed research directions represent fertile areas of investigation, particularly for South America, owing to the relative newness of accelerators in the region (Isabelle \& Del Sarto, 2020).

This study's findings suggest that the COO (Country-of-Origin) affects the startups in the first moments of their internationalization process, however the $\mathrm{COO}$ influences decreases as the startups develop, interact and exploit the new markets (Pestana, 2020).

Some of these are state-driven initiatives, like the pioneering Start-up Chile, which was followed by Start-up Brasil, StartUp Perú, Ruta N of Colombia, the National Institute of the Entrepreneur in Mexico, and the IncuBAte program in Argentina. Notable private accelerators in the region include 500 Startups, Startup Bootcamp, Wayra (of Telefónica), and BlueBox Ventures (IESE Business School and Wayra, 2020).

Within Latin America, some of the actors in this investment sector include Brazil's Monashees and Valor Capital, Argentina's Kaszek Ventures, Peru and Mexico's Angel Ventures and Mexico's ALLVP, MITA Ventures and Ignia (Lustig, 2019).

This may change. In the last few years, several Latin American countries have been advancing their start-up programs for companies near and far. The countries creating startup programs are offering 
grants for companies in the science and technology fields. Different programs are available in many countries, including: Chile, Brazil, Argentina, Columbia, Venezuela, Peru, and Ecuador (Silver, 2016).

Mexico is the fintech capital of Latin America with 158 startups dedicated to the sector. He is followed by Brazil (with 130 startups) and Colombia (with almost 80) (Gavasa, 2018).

Brazil was the first point of entry for investors from Silicon Valley, and it remains the epicentre for the region, but Argentina, Colombia, Mexico and Peru are also hotbeds of tech entrepreneurship (Baker, 2018).

In addition to the direct provision of financing through Innovate (including Startup Peru), the government of Peru has provided three years of financing for angel investor networks (Black, 2020).

In Latin America, there is significant progress in the creation and financing of startups.

\section{METHODOLOGY}

The research presents a qualitative-interpretative design, of a documentary type, which specified the selection procedure and the data recording (Barrero y Rosero, 2018).

In this research, 25 documents have been selected, carried out in the period 2016 - 2021; including: scientific articles, review articles and information from websites of recognized organizations. The keywords used in the searches were: Latin American and startups.

For the selection of the documents, the following criteria were used: the year of publication, belonging to the research and being a reliable source. After reading each document, the data was entered into the bibliographic matrix, which is used to catalog the documents according to categories, which are presented in Figure 1.

Table 1. Bibliographic matrix

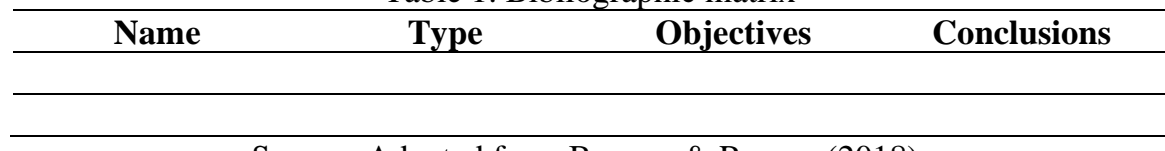

Source: Adapted from Barrero \& Rosero (2018).

\section{RESULTS}

Fintech startups are revolutionizing the financial industry across Latin America. These startups are some of the first providers of financial technology in the region and through their cross-border efforts, they are helping both consumers and companies monitor their finances, make payments, and receive loans (Legros, 2020). 
Figure 1. Entrepreneurial Ecosystem Strengthening Programs - Desired Impact

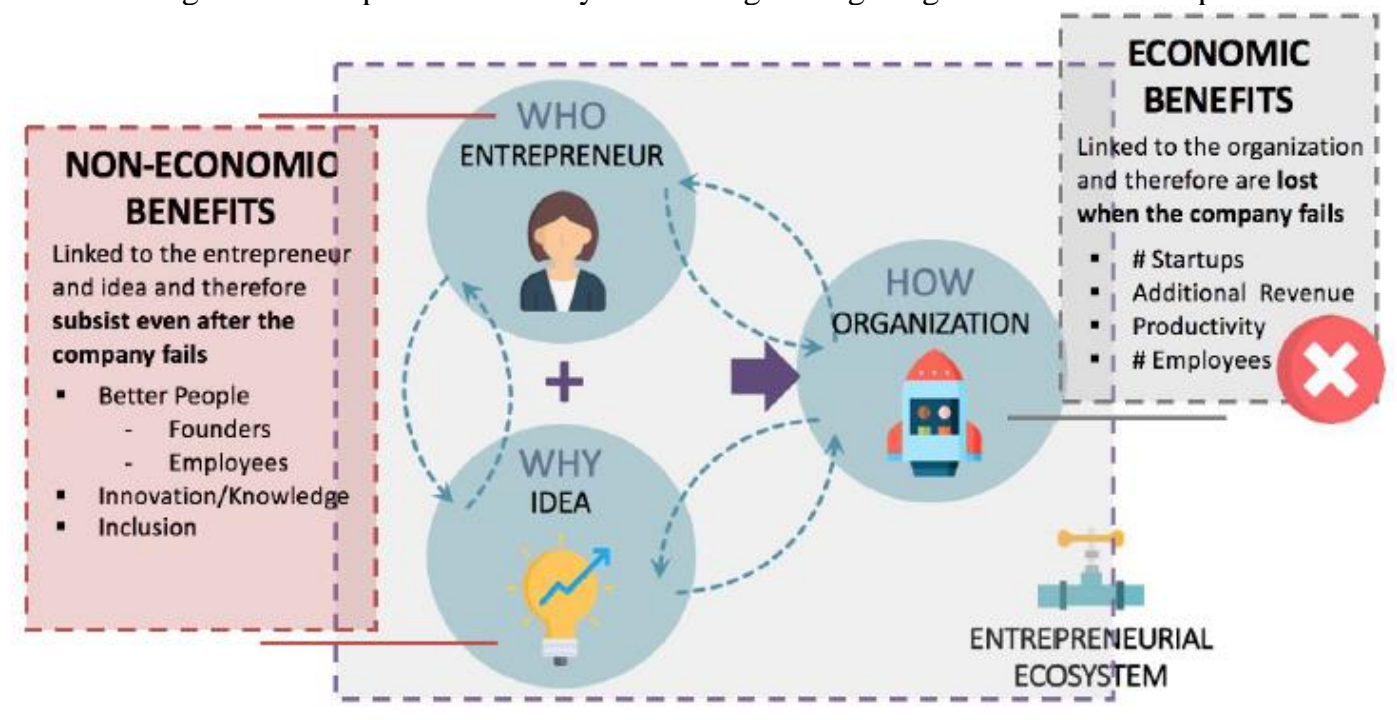

Source: Magendzo \& Castro (2019)

Figure 2. 2020 Startup Directory by the Numbers

STARTUPS BY SECTOR

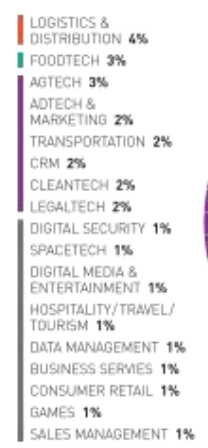

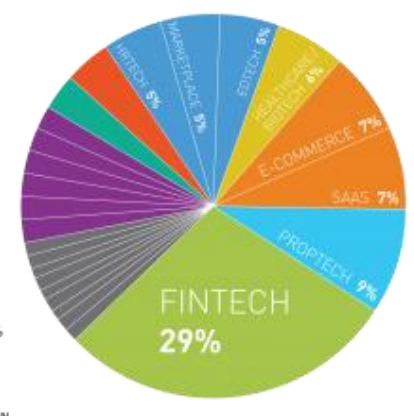

$29 \%$
STARTUPS BY STAGE

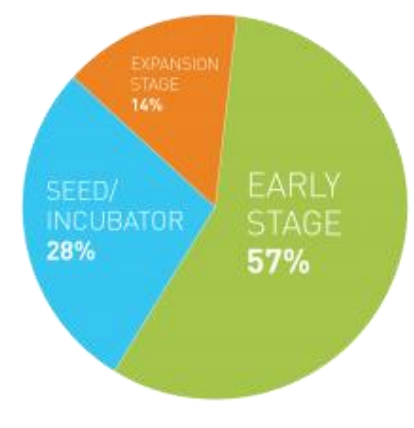

STARTUPS BY HQ

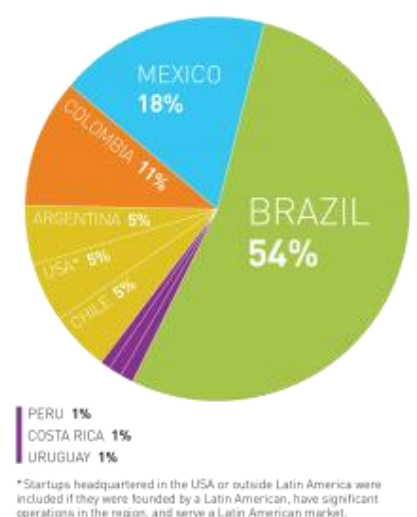

Source: LAVCA (2020)

The 12 Latin American finalists of the global MIT Inclusive Innovation Challenge are "reinventing the future of work in Latin America," according to the MIT Initiative on the Digital Economy (Somers, 2018). 
Figure 3. Latin American Startups Had Record Venture Capital Deals in 2020

\section{Record Deals}

Venture capital transactions in Latin America rose despite the pandemic

\section{number of transactions signed}

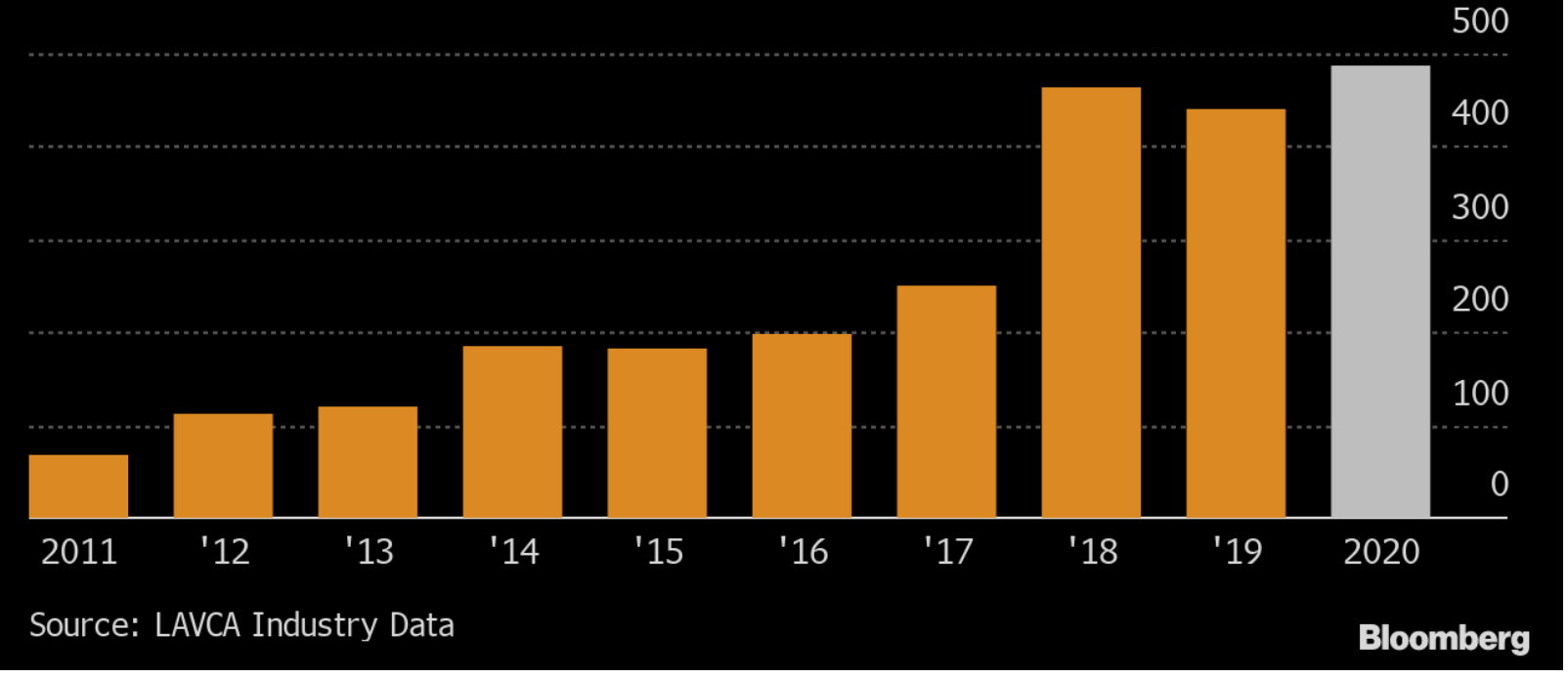

Source: Fieser (2021)

Table 2. The five action areas of direct policies to promote start-ups

\begin{tabular}{|c|c|c|}
\hline Gap & Policy action & Types of programmes/actions \\
\hline Funding gap & $\begin{array}{l}\text { Closing funding } \\
\text { gaps }\end{array}$ & $\begin{array}{l}\text { Seed-capital programmes and borrowing for start-ups, as well as incentives for the financial } \\
\text { sector to work with start-ups, such as the promotion of venture capital, angel investors, etc. In } \\
\text { recent years, countries have also introduced actions to support crowdfunding. }\end{array}$ \\
\hline $\begin{array}{l}\text { Information } \\
\text { asymmetry }\end{array}$ & $\begin{array}{l}\text { Facilitating linkages } \\
\text { and providing } \\
\text { services }\end{array}$ & $\begin{array}{l}\text { Support services for start-uppers. In recent years, platforms, mentoring networks and } \\
\text { collaborative workspaces have grown in number. They operate alongside traditional } \\
\text { intermediary institutions like incubators and accelerators. New platforms to facilitate linkages } \\
\text { between large firms and start-ups have also emerged. }\end{array}$ \\
\hline Absence of demand & Creating markets & $\begin{array}{l}\text { The inclusion of start-ups in public procurement programmes and initiatives that challenge } \\
\text { start-ups to provide innovative solutions. }\end{array}$ \\
\hline $\begin{array}{l}\text { Little tradition } \\
\text { for business and } \\
\text { innovation }\end{array}$ & $\begin{array}{l}\text { Transforming } \\
\text { mindsets }\end{array}$ & Actions to raise awareness about start-ups (including prizes and events). \\
\hline $\begin{array}{l}\text { Legal and } \\
\text { administrative } \\
\text { barriers }\end{array}$ & $\begin{array}{l}\text { Reforming legal } \\
\text { frameworks }\end{array}$ & $\begin{array}{l}\text { Legal and administrative reforms to suit the needs of start-ups, such as easier procedures for } \\
\text { starting and winding up a business. }\end{array}$ \\
\hline
\end{tabular}

Source: (OECD, 2016) 
Figure 4. Latin American companies

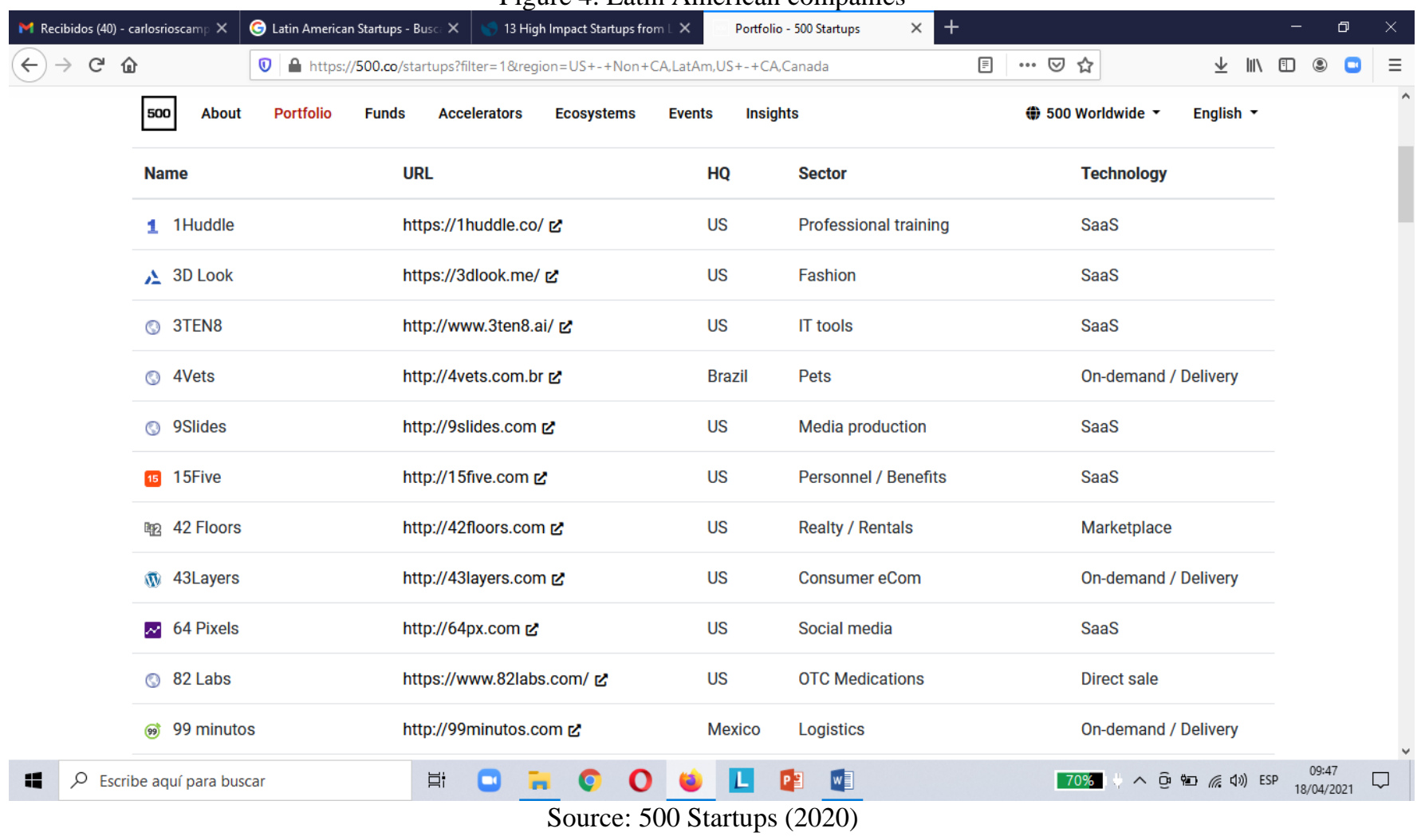

Table 3. Participants in Startup Weekend Women Edition, by profession and ethnicity. Years: 2018-2019

\begin{tabular}{lrrrrr}
\hline Profession & Asian & DNR & Latin & \multicolumn{2}{l}{$\begin{array}{l}\text { Native } \\
\text { American }\end{array}$} \\
\hline Businesswoman & 0 & 11 & 16 & 2 & 29 \\
Designer & 0 & 4 & 3 & 0 & 7 \\
Devoloper & 0 & 5 & 7 & 0 & 12 \\
Industry expert & 1 & 10 & 30 & 1 & 42 \\
\hline Total & 1 & 30 & 56 & 3 & 90 \\
\hline
\end{tabular}

Source: Roper, Mendoza \& Lau (2020).

In Table 3, the fifty-six participants were Latin, one Asian and three native American. 
Figure 5. Startup Continent: The Most Well-Funded Tech Startups In Latin America And The Caribbean

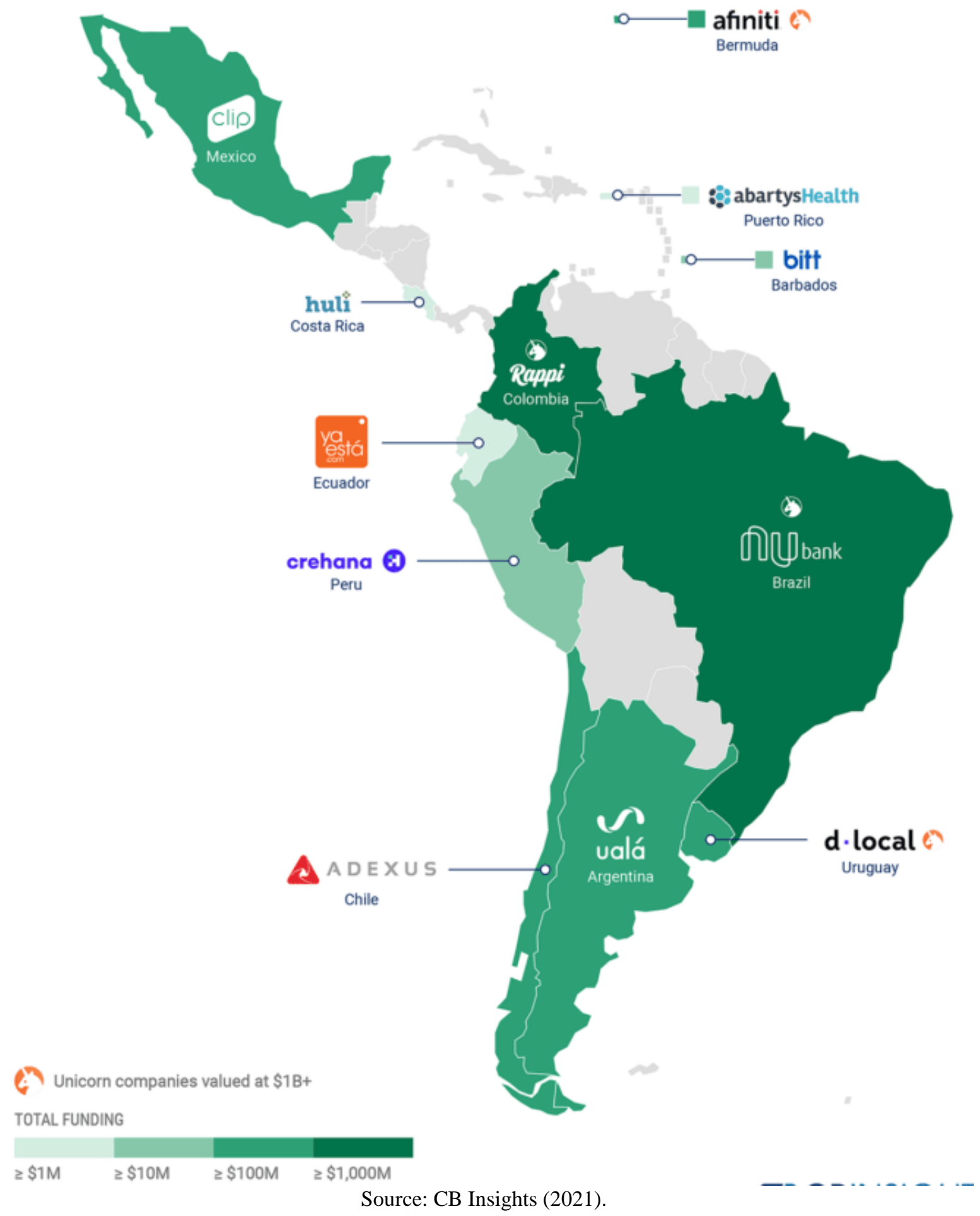

This momentum has held strong in 2021: as of March, the region has seen nearly \$1.3B in equity funding year-to-date. Top deals include a $\$ 400 \mathrm{M}$ Series $\mathrm{G}$ to challenger bank Nubank in January and a \$205M Series F to express delivery service Loggi in March (both companies are based in Brazil) (CB Insights, 2021). 
The Nubank Bank of Brazil and Rappi of Colombia are the unicorns companies, which are growing in Latin America in a sustained way and achieving a position, receiving more international financing. In addition, startups from other countries in the region are observed, which show significant growth and are recognized in new markets.

\section{CONCLUSIONS}

The situation of the Latin American Startups are: Fintech startups are revolutionizing the financial industry across Latin America, Latin American Startups Had Record Venture Capital Deals in 2020 and the Nubank Bank of Brazil and Rappi of Colombia are the unicorns companies. 


\section{BIBLIOGRAPHIC REFERENCES}

Baker, G. (2018). Latin American start-ups are thriving. Let's help them cross borders. Retrieved from https://www.weforum.org/agenda/2018/03/latin-american-startups-are-thriving-let-s-help-them-crossborders/

Barrero, A. \& Rosero, A. (2018). Estado del Arte sobre Concepciones de la Diversidad en el Contexto Escolar Infantil. Revista Latinoamericana de Educación Inclusiva, 2018, 12(1), 39-55 https://doi.org/10.4067/S0718-73782018000100004

Black, C. (2020). Financing for social entrepreneurship in Peru. https://apfcanadamsme.ca/sites/default/files/2020-02/Peru_Deetken\%20final.pdf

Castro, S. (2019). Latin American startups featured in Silicon Valley titan's latest report. Retrieved from https://andestimes.com/latin-american-startups-featured-in-silicon-valley-titans-latest-report/2196/

CB Insights (2021). Startup Continent: The Most Well-Funded Tech Startups In Latin America And The Caribbean. Retrieved from https://www.cbinsights.com/research/top-startups-latin-america-map/

Fieser, E. (2021). Latin American Startups Had Record Venture Capital Deals in 2020. Retrieved from https://www.bloomberg.com/news/articles/2021-03-16/latin-american-startups-had-record-venturecapital-deals-in-2020

Gavasa, J. (2018). These Latin American Startups are Revolutionizing the Fintech Sector. Retrieved from https://panamericanworld.com/en/magazine/startups/these-latin-american-startups-are-revolutionizingthe-fintech-sector/

González, B. (2017). The Latin American Community at HBS. Retrieved from https://www.hbs.edu/mba/blog/post/the-latin-american-community-at-hbs

IESE Business School and Wayra (2020). Corporate venturing in Latin America: Illuminating a blind spot. Retrieved from https://www.ieseinsight.com/doc.aspx?id=2273\&ar=16

Isabelle, D. A. ., \& Del Sarto, N. . (2020). ¿Cómo pueden evolucionar los aceleradores en Sudamérica para apoyar las iniciaciones en un mundo post-covid-19?. Multidisciplinary Business Review, 13(2), 6679. https://doi.org/10.35692/07183992.13.2.7

Kuschel, K., Lepeley, M.-T., Espinosa, F. and Gutiérrez, S. (2017). Funding challenges of Latin American women start-up founders in the technology industry. Cross Cultural \& Strategic Management, Vol. 24 No. 2, pp. 310-331. https://doi.org/10.1108/CCSM-03-2016-0072

LAVCA (2020). Latin American Startup Directory. Retrieved from https://lavca.org/vc/startup-directory Legros, S. (2020). 10 Cross-Border Latin American FinTech Startups To Watch. Retrieved from https://www.colombiafintech.co/novedades/10-cross-border-latin-american-fintech-startups-to-watch

Liberona D., Kumaresan A., Valenzuela L., Rojas C. \& Ferro R. (2019). Entrepreneurship Knowledge Insights in Emerging Markets Using a SECI Model Approach. In: Uden L., Ting IH., Corchado J. (eds) Knowledge Management in Organizations. KMO 2019. Communications in Computer and Information Science, vol 1027. Springer, Cham. https://doi.org/10.1007/978-3-030-21451-7_4 
Lustig, N. (2019). From seed to Series A: Scaling a startup in Latin America today. Retrieved from https://techcrunch.com/

Magendzo, A. \& Castro, J. (2019). An operational framework to evaluate non-economic benefits of entrepreneurial ecosystem development programs. Inter-American Development Bank. Retrieved from https://www.academia.edu/download/61824970/NonEconomic_Benefits_of_Entrepreneusrhip_-

_Paper_Versioun_Final20200118-66986-iic3qv.pdf

Mitchell, G. (2021). Predictions for Latin America's Startup Landscape in 2021. Retrieved from https://www.nasdaq.com/articles/predictions-for-latin-americas-startup-landscape-in-2021-2021-02-04

OECD (2016). Start-up Latin America 2016. Retrieved from https://www.oecd.org/dev/americas/Startups2016-Assessment-and-Recommendations.pdf

Pestana Neto, J. P. (2020). The Influence of Country-of-Origin (COO) Effects in Startups from Emerging Economiesin their Internationalization Process: A case study of Brazil's market and startups (Dissertation). Retrieved from http://urn.kb.se/resolve?urn=urn:nbn:se:hh:diva-42240

Roper, D., Mendoza, C. \& Lau, S. (2020). The Challenge of Inspiring Women Startups in a Latin American Country. Retrieved from http://ceur-ws.org/Vol-2709/paper171.pdf

Silver, A. (2016). Latin America's Startup Programs. Retrieved from https://www.panoramas.pitt.edu/health-and-society/latin-americas-startup-programs

Soh, A. (2019). Having It Both Ways: Can Latin American Spend More Money on Innovation and Reduce Income Inequality?. Latin American Policy, 10 (1), pp. 29-69. https://doi.org/10.1111/lamp.12159

Somers, M. (2018). These 12 startups are reimagining the Latin American workplace and workforce. Retrieved from https://mitsloan.mit.edu/ideas-made-to-matter/these-12-startups-are-reimagining-latinamerican-workplace-and-workforce

Taylor, A. (2017). Americas Quarterly; New York Tomo 11, N. ${ }^{\circ}$ 1, pp. 48-49.

500 Startups (2020). 500 Startups is more than just a name. Retrieved from https://500.co/startups?filter=1\&region=US+-+Non+CA,LatAm,US+-+CA,Canada 